Dila Antari, Karjuni Dt. Maani I Implementasi Kebijakan Program Sosial oleh Lembaga Konsultasi Kesejahteraan Keluarga(LK3) dalam Menangani Kasus Kekerasan dalam Rumah Tangga di Lubuk Alung Kabupaten Padang Pariaman

\title{
IMPLEMENTASI KEBIJAKAN PROGRAM SOSIAL OLEH LEMBAGA KONSULTASI KESEJAHTERAAN KELUARGA (LK3) DALAM MENANGANI KASUS KEKERASAN DALAM RUMAH TANGGA DI LUBUK ALUNG KABUPATEN PADANG PARIAMAN
}

\author{
Dila Antari ${ }^{1(a)}, K^{\text {Karjuni Dt. Maani }}{ }^{2(b)}$ \\ ${ }^{1}$ Jurusan Ilmu Administrasi Negara, Universitas Negeri Padang \\ ${ }^{2}$ Jurusan Ilmu Administrasi Negara, Universitas Negeri Padang \\ a)dilaantari16@gmail.com, ${ }^{b}$ karjuni.dtmaani@fis.unp.ac.id
}

\begin{abstract}
This research explains how the implementation of social program policies by the Family Welfare Consultation Institute (LK3) in handling domestic violence cases in Lubuk Alung, Padang Pariaman Regency, is that the Social Service has carried out socialization and counseling to the people of Padang Pariaman Regency, especially in Lubuk Alung, by visiting the district for inform about the LK3 Social Program in dealing with domestic violence. This socialization was also attended by the Head of Sub-district, Kapolsek, Wali Nagari, Wali Korong and other village officials. The objectives of this study are (1) to describe the implementation of social programs by LK3 in handling domestic violence cases in Lubuk Alung, Padang Pariaman Regency. (2) Identifying factors that influence the implementation of social programs by LK3 in handling cases of domestic violence in Lubuk Alung,PadangPariamanRegency. This research uses qualitative methods that are descriptive. The research location was conducted in Lubuk Alung, Padang Pariaman Regency. The data in this study were obtained from interviews, observation and documentation study. The research informants were the Head of Social Empowerment and Handling of the Poor, the Chairperson of LK3 Lubuk Alung in Padang Pariaman Regency, Wali Nagari, Wali Korong, Ninik Mamak, and the Lubuk Alung Community, Padang Pariaman Regency.Based on the results of research conducted at the P3A Social Service, Padang Pariaman Regency and the Family Welfare Consultation Institute (LK3) in Lubuk Alung, it can be concluded that: First, the Implementation of Social Programs by LK3 in handling cases of domestic violence in Lubuk Alung, Padang Pariaman District, P3A Social Service has implemented accordingly with the operational stages of policy implementation, namely there are 3 assessments, (1) interpretation, (2) organization, (3) Implication / application to the community in order to achieve an objective of the LK3 social program in dealing with domestic violence cases in Lubuk Alung, Padang Pariaman Regency. Second, the factors that influence the implementation of social programs by LK3 in handling domestic violence cases in Lubuk Alung, Padang Pariaman Regency consist of four factors that influence the implementation of the LK3 social program in handling cases of domestic violence in Lubuk Alung, Padang Pariaman Regency, namely communication, resources., disposition, and bureaucratic structure.
\end{abstract}

Keywords : Implementation, Implementation Factors, Family Welfare Consultation Institution (LK3)

Corresponding author. Email.dilaantari16@gmail.com

How to cite this article. Antari, D \& Ma'ani, K. (2020). Implementasi Kebijakan Program Sosial oleh Lembaga Konsultasi Kesejahteraan Keluarga (LK3) dalam Menangani Kasus Kekerasan dalam Rumah Tangga di Lubuk Alung Kabupaten Padang Pariaman. Jurnal Mahasiwa Ilmu Administrasi Publik (JMIAP) Jurusan Ilmu Administrasi Negara Fakultas Ilmu Sosial Universitas Negeri Padang, Volume 2 (3), Hal. 58-72.

http://jmiap.ppj.unp.ac.id

ISSN : 2684-818X (Online), ISSN : 2338-7378 (Print)

Copyright@2020. Published by Labor Jurusan Ilmu Administrasi Negara FIS UNP, Padang

58 | Jurnal Mahasiwa Ilmu Administrasi Publik | Volume 2 | Nomor $3 \mid$ Tahun 2020 | (Hal. 58-72) 
Dila Antari, Karjuni Dt. Maani I Implementasi Kebijakan Program Sosial oleh Lembaga Konsultasi Kesejahteraan Keluarga(LK3) dalam Menangani Kasus Kekerasan dalam Rumah Tangga di Lubuk Alung Kabupaten Padang Pariaman

\section{PENDAHULUAN}

Keluarga ialah kesatuan yang di peroleh dalam hubungan darah antara satu dengan lainnya. Dalam bentuk hubungan sosial, keluarga yaitu kesatuan yang diperoleh adanya saling berhubungan atau interaksi dan saling berkaitan antara satu dengan lainnya, meskipun diantara nya tidak terdapat hubungan darah. (Djamarah, 2014:3).

Keluarga adalah sekelompok primer yang sangat penting dalam masyarakat. Keluarga juga merupakan suatu group yang terbentuk dari hubungan laki-laki dan wanita,hubungan mana yang sedikit banyak berlangsung lama dalam menciptakan dan membesarkan anak-anak. Jadi keluarga yaitu dalam bentuk murni merupakan kesatuan sosial yang terdiri dari istri, suami dan anak-anak yang belum beranjak dewasa. kesatuan ini mempunyai perilaku tertentu yang sama, dan dimana saja dalam kesatuan masyarakat manusia. (Abu Ahmadi,2009).

Keluarga melaksanakan peranannya sebagai sistem sosial yang bisa dapat membentuk karakter serta dan moral seorang anak. Keluarga tidak hanya sebuah tempat berkumpulnya ibu,ayah dan anak, keluarga yang sebenarnya lebih dari itu. Keluarga juga menjadi tempat ternyaman bagi anak. Berawal dari keluarga semuanya bisa berkembang, sehingga mampu untuk mengaktualisasikan diri,besosialisasi, berpendapat, hingga berperilaku yang menyimpang.

Juga ada keluarga yang bisa menyelesaikan konflik secara baik dan sehat, dengan cara tidak mengendahulukan ego masing-masing,juga saling terbuka dan mau mendengarkan kritik maupun saran, hingga konflik atau masalah yang muncul dapat di jadikan penguat hubungan antar anggota keluarga, dan juga di jadikan sebagai pembelajaran. Ada juga keluarga yang memilih jalan kekerasan dan memaksakan kehendak dalam menyelesaian masalah. Terkadang muncul juga perilaku seperti memaksa, menyerang, mengancam hingga melakukan kekerasan fisik. Dan perilaku seperti ini juga dapat dikatakan sebagai tindakan kekerasan dalam rumah tangga (KDRT). Biasanya anggota yang mempunyai wewenang lebih besar dari anggota keluarga lainnya lah melakukan tindak kekerasan maupun pemaksaan. Tindakan kekerasan yang dilakukan anggota keluarga terhadap anggota keluarga lainnya ini lah yang biasa di sebut Kekerasan Dalam Rumah Tangga (KDRT). (Fauziyya, 2014).

Dari menurut data Lembar Fakta Catatan Tahunan (CATAHU) Komnas perempuan(www.komnasperempuan.go.id) memperlihatkan angka kekerasan terhadap perempuan dari tahun ke tahun mengalami peningkatan dengan kekerasan personel terhadap istri yang paling tinggi. Pada Tahun 2017 tercatat 348,446 kasus, pada tahun 2018 tercatat 406,178 kasus, data terbaru tahun 2019 sebanyak 431,471 kasus. Bentuk KDRT yang sering terjadi adalah penganiayaan, pemukulan,penelantaran, penyekapan, penyiksaan, bahkan yang tak jarang menyebabkan kematian.

Undang-undang Hukum Pidana Pasal 1 nomor 23 tahun 2004 tentang penghapusan KDRT dan seharusnya berfungsi sebagai penekan angka KDRT, karena merupakan suatu bentuk pelanggaran hukum yang telah diatur sebagaimana di dalamnya pelaku kekerasan akan mendapat ancaman hukum. Tetapi bukti dilapangan Undang-Undang tersebut kurang dapat melindungi perempuan. Dalam kerjanya, para penegak hukum seringkali tidak responsif terhadap masalah ini karena sering dianggap suatu masalah privasi. Fokus dari UndangUndang PKDRT ini yaitu kepada upaya pencegahan, perlindungan, dan pemulihan korban KDRT.

Selain usaha pencegahan, dan usaha penangulangan juga tak kalah penting. Korban KDRT juga di perlukan penanganan yang tepat untuk memulihkan kondisi psikologis dan kehidupan sosialnya di masyarakat. Kekerasan yang dialami oleh 
Dila Antari, Karjuni Dt. Maani I Implementasi Kebijakan Program Sosial oleh Lembaga Konsultasi Kesejahteraan Keluarga(LK3) dalam Menangani Kasus Kekerasan dalam Rumah Tangga di Lubuk Alung Kabupaten Padang Pariaman

seorang istri akan mengakibatkan tekanantekanan psikologis, yang mana istri juga mempunyai hak untuk hidup layak dalam keluarga. Maka dari itu istri yang merupakan korban KDRT perlu untuk dibina dan diarahkan untuk meningkatkan kondisi mental psikologis dan kepercayaan diri mereka agar mampu meningkatkan semangat hidup serta juga mampu menyesuaikan dengan norma-norma kehidupan di masyarakat agar mampu mewujudkan suatu kemandirian sehingga mampu untuk meningkatkan kualitas kehidupan.

Upaya pencegahan, perlindungan, dan pemulihan korban KDRT, ada beberapa pihak seperti pekerja sosial, advokat, lembaga sosial, harus bekerja sama dalam untuk mewujudkan tujuan penghapusan KDRT. Dari melalui Peraturan Menteri Sosial pada tahun 2010 mengeluarkan Peraturan Menteri Sosial Republik Indonesia No. 84 Tahun 2010 tentang mengenai Program Sosial Lembaga Konsultasi Kesejahteraan Keluarga (LK3).

Lembaga Konsultasi Kesejahteraan Keluarga (LK3) adalah salah satu tempat penangan masalah sosial psikologis keluarga yang mengedepankan pendekatan pekerjaan sosial,dalam proses pelayanan dan dukungannya dari disiplin ilmu yang terkait. Pelayanan yang diberikan oleh LK3 yaitu antara lain pemberian informasi, konsultasi, konseling, advokasi secara profesional, dan serta merujuk sasaran ke lembaga pelayanan lain yang benar-benar mampu untuk memecahkan masalah secara lebih intensif. Dan ejalan dengan makin kompleknya masalahan keluarga, maka juga diperlukan mekanisme penanganan permasalahan yang lebih dekat dengan kelompok sasaran. (Samsudin, 2019).

Kementerian Sosial ataupun pemerintah daerah dalam meningkatkan keberlanjutan program ini. Pengembangan LK3 Kabupaten atau Kota maupun LK3 berbasis masyarakat, diharapkan dapat menjadi media dalam penanganan masalah sosial psikologis keluarga yang semakin meningkat baik kualitas ataupun kompleksitasnya. (Nasserie, 2004).

Lembaga Konsultasi Kesejahteraan Keluarga (LK3) merupakan lembaga atau organisasi yang memberikan pelayanan konseling, konsultasi, penyebarluasan atau pemberian informasi, penjangkauan, pendampingan, perlindungan dan pemberdayaan keluarga secara profesional, termasuk juga merujuk sasaran ke lembaga pelayanan lain, yang mampu memecahkan masalahnya.

Pemerintah Kabupaten Padang Pariaman melakukan inovasi baru dalam memberikan pelayanan konseling keluarga untuk masyarakat dengan membuat kebijakan yang di namai program Sosial Lembaga Konsultasi Kesejahteraan Keluarga (LK3). Program LK3 ini dicanangkan dari tahun 2010 melalui Peraturan Menteri Sosial Republik Indonesia No 84 Tahun 2010 tentang Program Sosial Lembaga Konsultasi Kesejahteraan Keluarga. Program LK3 ini bertujuan untuk membantu meningkatkan kemampuan individu, keluarga,maupun masyarakat dalam mengatasi permasalahan sosial. Maka dari itu juga memperkuat dan memelihara kehidupan keluarga yang harmonis agar dapat melaksanakan fungsi sosial secara optimal.

Berdasarkan Peraturan Menteri Sosial Republik Indonesia Nomor 25 Tahun 2017 Bab I Pasal 2 menjelaskan bahwa LK3 bertujuan untuk:

a. Mengatasi masalah Psikososial Keluarga

b. Memulihkan kondisi Psikososial keluarga

c. Meningkatkan kesejahteraan keluarga

d. Memperkuat ketahanan keluarga

Yang mana bentuk kepedulian terhadap masalah yang ada di dalam keluarga. Program ini menjadi penting untuk mengatasi persoalan keluarga yang bermasalah sosial psikologis seperti, Kekerasan Dalam Rumah Tangga (KDRT), Perceraian, anak terlantar, masalah ekonomi dan lanjut usia, narkoba dan 
Dila Antari, Karjuni Dt. Maani I Implementasi Kebijakan Program Sosial oleh Lembaga Konsultasi Kesejahteraan Keluarga(LK3) dalam Menangani Kasus Kekerasan dalam Rumah Tangga di Lubuk Alung Kabupaten Padang Pariaman

masalah sosial lainnya, semua permasalahan ini dapat terselesaikan dengan merujuk ke lembaga yang relevan dalam menyelesaikan masalahnya.

Dinas Kesejahteraan Sosial Republik Indonesia, mengklasifikasikan keluarga bermasalah sebagai Penyandang Masalah Kesejahteraan Sosial (PMKS) merupakan seseorang atau keluarga yang dikarenakan suatu hambatan, kesulitan atau gangguan tidak dapat melaksanakan fungsi sosialnya, dan dikarenakan tidak dapat menjalin hubungan yang serasi dan kreatif dengan lingkungannya, sehingga tidak dapat memenuhi kebutuhan hidupnya (jasmani, rohani dan sosial) secara memadai dan wajar. Upaya yang telah dilakukan pemerintah saat sekarang ini untuk mengatasi permasalahan tingginya kasus keluarga-keluarga bermasalah salah satunya yaitu dengan membentuk badanbadan yang secara khusus bertujuan untuk meminimalisirkan bahkan untuk mengatasi permasalahan tersebut. LK3 atau Lembaga Konsultasi Kesejahteraan Keluarga adalah salah satu lembaga sosial yang menangani permasalahan yang terjadi dalam keluarga.

Namun pada kenyataannya, walaupun Lembaga Konsultasi Kesejahteraan Keluarga (LK3) sudah didirikan tetapi keluarga juga jarang menggunakan pelayanan fasilitas tersebut untuk konsultasi atau memecahkan sebuah masalah yang terjadi dalam keluarga. Masyarakat tersebut bisa dikatakan tidak paham atau tidak mengerti tentang apa tujuan dan manfaat dari LK3 tersebut.

Dari hasil survey dan pengambilan data yang peneliti lakukan, dalam pelaksanaan program sosial Lembaga Konsultasi Kesejahteraan Keluarga (LK3) di Lubuk Alung Kabupaten Padang Pariaman, masih terdapat beberapa masalah dalam pelaksanaannya salah satu nya adalah masih tingginya angka perceraian dan KDRT di daerah Lubuk Alung Kabupaten Padang Pariaman, dimana data yang didapat menunjukkan bahwa angka perceraian di Lubuk Alung tahun 2019 sebanyak 12 orang, dan KDRT 16 keluarga, sehingga tercatat 28 permasalahan yang tercatat. Semantara keluarga yang konsul tercatat sebanyak 25 orang.Seharusnya angka konsul ke LK3 ini harus lebih tinggi dibandingkan dengan data yang tercatat.Hal ini membuktikan masih kurangnya partisipasi dan kesadaran masyarakat terhadap Program Sosial Oleh Lembaga Konsultasi Kesejahteraan Keluarga (LK3) di Lubuk Alung Kabupaten Padang Pariaman.

Maka selain itu yang menjadi faktor penghambat pelaksanaan Program Sosial Lembaga Konsultasi Kesejahteraan Keluarga (LK3) yaitu kurang nya sosialisasi pemerintah kepada masyarakat, sehingga masih banyak masyarakat kurang mengetahui Program Sosial Lembaga Konsultasi Kesejahteraan Keluarga (LK3) ini.

Sosialisasi yang dilakukan oleh pemerintah masih kurang optimal dikarenakan masih banyak masyarakat yang belum mengetahui tentang Program Sosial Lembaga Konsultasi Kesejaahteraan Keluarga (LK3) dalam menangani kasus KDRT ini. Peran serta partisipasi masyarakat untuk mensukseskan Program Sosial Lembaga Konsultasi Kesejahteraan Keluarga (LK3) dalam menangani kasus KDRT masih rendah. Masih ada masyarakat yang tidak ingin berkunjung untuk berkonsultasi ke lembaga konsultasi kesejahteraan keluarga (LK3). Dan tingkat pendidikan masyarakat yang rendah juga berpengaruh terhadap pola pikir masyarakat, Mereka bisa dikatakan tidak paham dan tidak mengerti tentang apa tujuan dan manfaat dari LK3 tersebut. Dan disini peran pemerintah sangat di butuhkan agar pemerintah melakukan sosialisasi kepada masyarakat agar masyarakat setempat lebih mengetahui apa itu Lembaga Konsultasi Kesejahteraan Keluarga (LK3) dalam menangani kasus KDRT dan apa kegunaan dan tujuan nya pemerintah untuk membuat program sosial Lembaga Konsultasi Kesejahteraan Keluarga. Agar 
Dila Antari, Karjuni Dt. Maani I Implementasi Kebijakan Program Sosial oleh Lembaga Konsultasi Kesejahteraan Keluarga(LK3) dalam Menangani Kasus Kekerasan dalam Rumah Tangga di Lubuk Alung Kabupaten Padang Pariaman

masyarakat setempat itu paham apa tujuan dan manfaat dari program sosial LK3 ini. Dan dari hasil wawancara tersebut juga terlihat bahwa kesadaran dan partisipasi masyarakat menjadi salah satu hambatan dalam pelaksanaan program sosial lembaga konsultasi kesejahteraan keluarga dalam menangani kasus KDRT di Lubuk Alung. Oleh karena itu, sosialisasi harus selalu dilakukan supaya terciptanya partisipasi dari masyarakat terhadap program tersebut.

Berdasarkan pernyataan tersebut perlu di lihat kembali sejauh mana Program Sosial Lembaga Konsultasi Kesejahteraan Keluarga (LK3) dalam menangani kasus KDRT dapat efektif dalam meningkatkan kesejahteraan keluarga masyarakat, serta sudah berjalan baik atau tidak pelaksanaanya hingga saat ini. Oleh dari itu, penulis tertarik untuk melakukan penelitian dengan judul "Implementasi Kebijakan Program Sosial Oleh Lembaga Konsultasi Kesejahteraan Keluarga (LK3) Dalam Menangani Kasus Kekerasan Dalam Rumah Tangga di Lubuk Alung Kabupaten Padang Pariaman.”

\section{TINJAUAN PUSTAKA}

\section{Konsep Kebijakan Publik}

Kebijakan publik pada hakikatnya dibuat pemerintah berupa tindakan-tindakan pemerintah. Kebijakan publik, baik untuk melakukan maupun tidak melakukan sesuatu yang mempunyai tujuan tertentu. Kebijakan publik biasanya ditujukan untuk kepentingan masyarakat. kebijakan publik bertujuan, untuk seperangkat tindakan pemerintah yang didesain untuk mencapai hasil-hasil tertentu yang diharapkan oleh publik sebagai konstituen pemerintah. Kebijakan publik sebagai untuk tindakan yang sah karena kebijakan publik itu sendiri dibuat oleh lembaga yang memiliki legitimasi dalam pemerintahan. Dan kemudian kebijakan publik yaitu sebagai hipotesis yang merupakan kebijakan yang dibuat berdasarkan teori, hipotesis,atau model mengenai sebab dan akibat. Kebijakan biasa bersandar pada asumsi- asumsi menganai sifat dan perilaku. (Anggara, 2014:36).

Kebijakan publik yaitu rumusan keputusan pemerintah yang merupakan pedoman untuk mengatasi masalah publik yang mempunyai tujuan, rencana dan program yang dilaksanakan secara jelas. Kebijakan publik pada dasarnya merupakan suatu hal keputusan yang dimaksudkan untuk mengatasi kesalahan tertentu yang melakukan kegiatan tertentu, atau untuk mencapai tujuan tertentu yang dilakukan oleh instansi atau pemerintah yang mempunyai wewenang dalam rangka penyelenggaraan tugas pemerintah negara dan pembangunan, dan berlangsung suatu dalam kebijakan tertentu. Kebijakan publik dapat dibagi menjadi dua kelompok dalam arti luas, yaitu kebijakan dalam bentuk peraturan-peraturan pemerintah yang tertulis dalam bentuk peraturan perundangundangan,peraturan-peraturan yang tidak tertulis namun disepakati, yaitu yang biasa disebut konvensi-konvensi. Kebijakan Publik adalah suatu proses formulasi, evaluasi dan implementasi kebijakan yang berkesinambungan dan saling keterkaitan, yang dikerjakan oleh pemerintah dengan stakeholder dalam mengatur, mengelola dan menyelesaikan berbagai urusan publik,sumber daya dan masalah yang ada untuk kemaslahatan publik. (Mulyadi, 2016: 36-37).

\section{Implementasi Kebijakan Program}

Implementasi adalah yang merupakan langkah yang sangat penting di dalam proses kebijakan. Kebijakan banyak yang baik mampu dibuat oleh pemerintah, akan tetapi kemudian tidak mempunyai pengaruh apa-apa dalam kehidupan negara tersebut karena tidak dilaksanakan. Orang-orang juga sering beranggapan bahwa implementasi yaitu hanya pelaksanaan dari apa yang telah diputuskan legislatif atau pengambil keputusan, dan seolah-olah ini tahapan nya kurang berpengaruh. Namun dalam kenyataanya dapat kita lihat bahwa apapun baiknya rencana yang dibuat tetapi 
Dila Antari, Karjuni Dt. Maani I Implementasi Kebijakan Program Sosial oleh Lembaga Konsultasi Kesejahteraan Keluarga(LK3) dalam Menangani Kasus Kekerasan dalam Rumah Tangga di Lubuk Alung Kabupaten Padang Pariaman

tidak ada gunanya apabila itu tidak dilaksanakan dengan baik dan benar. Implementasi juga sering digunakan sebagai tempat melayani kepentingan individu dan kelompok, Implementasi pada dasarnya operasionalisasi dari berbagai aktivitas untuk mencapai suatu tujuan. (Pasolong, 2007:57).

Implementasi kebijakan adalah hal yang terpenting pada kebijakan. Pada tahap ini menentukan apakah kebijakan yang ditempuh pemerintah benar-benar aplikabel atau diterima di lapangan dan berhasil untuk guna menghasilkan output dan outcomes seperti yang telah direncanakan. Output yaitu keluaran kebijakan yang diharapkan dapat muncul seperti keluaran langsung dari kebijakan. Output juga biasanya dapat dilihat dalam waktu yang pasca singkat atau setelah implementasi kebijakan. Outcomes merupakan akibat setelah keluarnya output kebijakan, dari kebijakan yang diharapkan juga dapat timbul. Outcomes biasanya diukur keluarnya setelah output atau dalam jangka waktu yang lama pasca implementasi kebijakan (Dwiyanto 2009:143).

Implementasi kebijakan publik adalah suatu aktivitas kebijakan publik dalam proses yang menentukan apakah sebuah kebijakan itu diterima oleh publik,atau bersentuhan dengan kepentingan publik. Dalam hal ini juga ditekankan yang mana bisa dalam formulasi dan tahapan perencanaan kebijakan dapat kita lakukan dengan sebaik-baiknya, akan tetapi pada tahapan implementasinya tidak diperhatikan optimalisasinya, maka dari itu tentu kurang jelas apa yang diharapkan dari sebuah pokok kebijakan itu. (Aneta, 2010:55).

Dari definisi di atas Dapat disimpulkan bahwa Implementasi kebijakan mengaitkan tiga hal yaitu : (1) Adanya sasaran kebijakan dan tujuannya, (2) Adanya aktivitas yang merupakan kegiatan untuk mencapai tujuan, (3) Adanya hasil dari kegiatan.

Suatu program tidak hanya merupakan kegiatan tunggal yang dapat terselesaikan dalam jangka waktu yang singkat, akan tetapi kegiatan merupakan yang berkesinambungan karena melaksanakan suatu kebijakan. Dan karena itu lah sebuah program dapat berlangsung dalam kurun waktu yang relatif lama. berhubungan dengan pengertian program secara umum yaitu merupakan suatu unit atau kesatuan kegiatan, maka program merupakan suatu sistem, dan rangkaian kegiatan yang dilaksanakan tidak hanya satu kali akan tetapi berkesinambungan. Pelaksanaan program akan selalu terjadi di dalam sebuah organisasi yang mana dapat di artikan harus melibatkan sekelompok orang (Suharsimi, 2010:4).

Menurut Charles O. Jones dalam Suryana (2009:28) ada tiga tahapan dalam mengoperasikan program yaitu :

1) Interpretasi, bagi para pelaksana mampu menjalankan program sesuai dengan petunjuk teknis dan petunjuk pelaksana agar suatu tujuan yang diharapkan dapat dicapai.

2) Pengorganisasian, merupakan Struktur organisasi yang tepat dan jelas yang diperlukan dalam mengoperasikan program hingga tenaga pelaksana dapat dibentuk dari sumber daya manusia yang berkualitas.

3) Penerapan atau Aplikasi, yaitu Perlu adanya rangkaian prosedur kerja berjalan sesuai dengan jadwal kegiatan dan sehingga tidak berbenturan dengan program lainnya.

Model implementasi ebijakan publik menurut Edward III mempunyai ada 4 Faktor yang dapat mempengaruhi peran penting dalam mencapaian keberhasilan suatu implementasi. yang mana empat Faktor-faktor yang mempengaruhi Implementasi Kebijakan Program adalah (Dwiyanto Indiahono 2009:31) sebagai berikut :

1) Komunikasi, adalah menunjukan bahwa dalam setiap kebijakan bisa dilaksanakan dengan baik apabila terjadi komunikasi yang efektif diantara pelaksana program atau kebijakan 
Dila Antari, Karjuni Dt. Maani I Implementasi Kebijakan Program Sosial oleh Lembaga Konsultasi Kesejahteraan Keluarga(LK3) dalam Menangani Kasus Kekerasan dalam Rumah Tangga di Lubuk Alung Kabupaten Padang Pariaman

dengan antara kelompok sasaran atau target grup. Dan hal itu bertujuan agar bisa disosialisasikan secara baik, program dan kebijakan dapat menghindari adanya distorsi. Yang mana hal ini sangat penting untuk mengurangi tingkat penolakan dan kekeliruan terhadap program dan kebijakan yang ada.

2) Suber Daya, Sumber daya adalah yang merupakan faktor yang penting untuk mengimplementasikan kebijakan agar berjalan efektif. . Dalam setiap kebijakan harus didukungkan oleh sumber daya yang memadai, yang mana baik sumber daya manusia maupun sumber daya financial. Sumber daya manusia merupakan kecukupan baik kualitas ataupun implementor kuantitas bisa sasaran kelompok melingkupi sasaran. Yang mana menurut George $\mathrm{C}$. Edward III yang mana meliputi sumber daya manusia, sumber daya peralatan, dan sumber daya kewenangan dan sumber daya anggaran.

3) Disposisi, dalam dispiosisi implementasi kebijakan terdiri dari pertama, pengangkatan birokrasi dan kedua intensif.

4) Struktur Birokrasi, di dalam struktur birokrasi menjadi hal yang penting dalam implementasi kebijakan. Yang mana aspek struktur birokrasi ini mencangkup dua hal yang penting, yaitu, Mekanisme, Struktur Organisasi Pelaksanaan.

\section{Program Sosial Lembaga Konsultasi Kesejahteraan Keluarga (LK3) Dalam Menangani Kasus Kekerasan Dalam Rumah Tangga}

Program merupakan interpretasi dari sebuah kebijakan pemerintah yang berisi kumpulan instruksi, yang dibuat untuk memperbaiki dalam menyelesaikan permasalahan dimana sedang berkembang. Program pemerintah yang fokus menjadi kajian peneliti yaitu program sosial lembaga konsultasi kesejahteraan keluarga
(LK3) dalam menangani kasusu kekerasan dalam rumah tangga di Lubuk Alung Kabupaten Padang Pariaman. Program ini dibuat karena banyak nya permasalahan keesejahteraan keluarga di Lubuk Alung Kabupaten Padang Pariaman. Maksud di buat nya program sosial lembaga konsultasi kesejahteraan keluarga (LK3) dalam menangani kasusu kekerasan dalam rumah tangga di Lubuk Alung Kabupaten Padang Pariaman ini adalah memberikan layanan konsultasi dan konseling bagi keluarga yang mempunyai masalah KDRT atau pun sosial lainnya yang ada pada masyarakat yang berkeadilantanpa diskriminasi dan menjunjung tinggi nilai-nilai kemanusia untuk mendapatkan pelayanan yang maksimal. Maka dari itu dibuatlah program sosial lembaga konsultasi kesejahteraan keluarga (LK3) dalam menangani kasus kekerasan dalam rumah tangga ini yang bertujuan untuk meningkatnya kemampuan keluarga dalam memahami dan memecahkan masalah mereka sendiri, yang pada akhirnya diharapkan dapat terwujud keluarga harmonis.

\section{METODE PENELITIAN}

Penelitian ini merupakan penelitian deskripstif dengan menggunakan pendekatan kualitatif. Metode ini menjelaskan atau menggambarkan permasalahan yang ada dengan memberikan jawaban atau permasalahan yang di kemukakan. Melalui penelitian kualitatif deskriptif, peneliti bermaksud untuk sesuai dengan apa yang terjadi dilapangan menggambarakan kejadian fenomena serta yang di hasilkan berupa data,kata-kata tertulis atau lisan dari orangorang dan perilaku yang diamati, yang berkaitan dengan Implementasi Kebijakan Program Sosial LK3 Dalam Menangani Kasus Kekerasan Dalam Rumah Tangga di Lubuk Alung Kabupaten Padang Pariaman oleh Dinas Sosial Pemberdayaan Perempuan dan Perlindungan Anak di Kabupaten Padang Pariaman secara 
Dila Antari, Karjuni Dt. Maani I Implementasi Kebijakan Program Sosial oleh Lembaga Konsultasi Kesejahteraan Keluarga(LK3) dalam Menangani Kasus Kekerasan dalam Rumah Tangga di Lubuk Alung Kabupaten Padang Pariaman

sistematis dan yang ada di lapangan sesuai dengan fakta.

Lokasi yang menjadi tempat peneliti ini yaitu Instansi Pemerintah di Kantor Dinas Sosial Pemberdayaan Perempuan dan Perlindungan Anak Kabupaten Padang Pariaman dan Kantor Lembaga Konsultasi Kesejahteraan Keluarga (LK3) di Lubuk Alung Kabupaten Padang Pariaman, beserta Masyarakat di Lubuk Alung Kabupaten Padang Pariaman, dikarenakan dukungan dari data yang menunjukkan kurangnya kunjungan serta partisipasi masyarakat dalam memanfaatkan LK3.

Pengambilan informan dalam penelitian ini menggunakan teknik Purposive Sampling. Purposive sampling merupakan teknik pengambilan informan yang dilakukan dengan pertimbangan tertentu yang bertujuan agar data yang diperoleh nantinya menjadi lebih representatif (menggambarkan masalah). Penulis membagi data penelitian ini ke dalam 2 (dua) jenis yaitu:

1) Data Primer yaitu merupakan data yang berkaitan dengan fokus penelitian dan juga merupakan hasil pengumpulan peneliti sendiri selama berada di lokasi penelitian.

2) Data Sekunder yaitu merupakan data yang diperoleh untuk melengkapi data primer yang mana juga diperoleh secara langsung melalui buku, arsip dan dokumen-dokumen segala bentuk informasi yang bersifat menunjang dan mendukung penelitian ini. Sebagai informasi yang mendukung dalam analisis data primer tambahan yang berasal dari sumber tertulis di gunakan sebagai informasi.

Teknik pengumpulan data dalam penelitian ini yang dilakukan oleh peneliti adalah dengan melalui tiga metode, yaitu : 1) Wawancara, wawancara yang dilakukan dengan wawancara secara langsung tanya jawab dengan objek informasi dijadikan memperoleh data yang sesuai dengan permasalahan penelitian untuk yang sedang diteliti yakni mengenai pelaksanaan program Lembaga Konsultasi

Kesejahteraan Keluarga (LK3) di Lubuk Alung Kabupaten Padang Pariaman. 2) Observasi, Dalam penelitian ini,subjek penelitian terkait Implementasi Kebijakan Program Sosial Oleh Lembaga Konsultasi Kesejahteraan Keluarga (LK3) di Lubuk Alung Kabupaten padang pariaman peneliti berupaya memahami dan mengamati. Penulis melakukan penelitian dari 6 maret 2020 yang berawal dari pengambilan data awal di Kantor Lembaga Konsultasi Kesejahteaan Keluarga (LK3) dan beberapa masyarakat Lubuk Alung kabupaten padang pariaman. 3) Dokumentasi, yang mana fokus permasalahan yang diteliti, mana dalam hal ini peneliti mempelajari dokumen-dokumen yang berhubungan dengan pemasalahan mengenai permasalahan pelaksanaan program Lembaga Konsultasi Kesejahteraan Keluarga (LK3). Teknik ini digunakan untuk mempertajam dan memperkuat data yang telah peneliti peroleh dilapangan.

Dalam penelitian ini dilakukan dengan triangulasi,yang mana untuk mendapatkan keabsahan data. Adapun triangulasi adalah sebagai pembanding terhadap data yang memanfaatkan sesuatu yang lain di luar data itu untuk sebagai perbandingan terhadap data dan untuk keperluan pengecekan data itu (Moleong, 2013:330).

Teknik analisis data penelitian ini adalah menggunakan langkah-langkah seperti yang dikemukakan oleh Burhan Bungin (2003:70), yaitu sebagai berikut:

1) Pengumpulan Data (Data Collection). Kegiatan pengumpulan data menggunakan wawancara dan studi dokumentasi pada penelitian ini.

2) Reduksi Data (Data Reduction). Reduksi dilakukan dengan maksud menyisihkan data/informasi yang tidak relevan sejak pengumpulan data dimulai dengan membuat ringkasan, mengkode, menelusur tema, membuat gugusgugus, menulis memo dan sebagainya.

3) Display Data. Display data adalah tindakan pengambilan adanya 
Dila Antari, Karjuni Dt. Maani I Implementasi Kebijakan Program Sosial oleh Lembaga Konsultasi Kesejahteraan Keluarga(LK3) dalam Menangani Kasus Kekerasan dalam Rumah Tangga di Lubuk Alung Kabupaten Padang Pariaman

penarikan kesimpulan dan pendeskripsian sekumpulan informasi tersusun yang memberikan kemungkinan.

4) Verifikasi dan Penegasan Kesimpulan (Conclution Drawing and Verification) yaitu data yang telah disajikan menemukan makna Setelah dilakukan tiga tahapan diatas maka dilakukan pengesahan kesimpulan dan verifikasi yang merupakan analisis data dari kegiatan akhir . berupa Penarikan kesimpulan kegiatan interpretasi,

\section{HASIL DAN PEMBAHASAN Implementasi Kebijakan Program Sosial Oleh LK3 dalam Menangani Kasus Kekerasan Dalam Rumah Tangga di Lubuk Alung Kabupaten Padang Pariaman}

Pemerintah Kabupaten Padang Pariaman melakukan berbagai inovasi khususnya dalam aspek pelayanan sosial. Pemerintah Kabupaten padang pariaman melalui Dinas sosial pemberdayaan perempuan dan perlindungan anak Kabupaten padang pariaman membuat sebuah kebijakan yang berkaitan dengan pelayanan Sosial yang disebut dengan Program Sosial LK3 dalam kasus KDRT. Tujuan dari Program Sosial LK3 dalam kasus KDRT ini adalah meningkatkan kemampuan individu, keluarga, masyarakat untuk membantu mengatasi permasalahan keluarga. Dan selain dengan adanya Program Sosial LK3 dalam menangani kasus KDRT ini melaksanakan fungsi sosial secara optimal juga memelihara dan memperkuat kehidupan keluarga agar dapat yang harmonis. Dalam melihat bagaimana Implementasi Kebijakan Program Sosial LK3 dalam menangani kasus kekerasan dalam rumah tangga penulis melakukan penelitian khususnya di Lubuk Alung, maka dari itu penulis menggunakan teori Charles O. Jones dalam implementasi sebuah kebijakan bahwa menyatakan ada 3 (tiga) penilaian tahapan operasional, yaitu : a) interpretasi, b) pengorganisasi, dan c) implikasi/penerapan.

\section{Interpretasi}

Untuk mengetahui agar program sosial LK3 dalam menangani kasus kekerasan dalam rumah tangga dengan petunjuk pelaksana dan petunjuk teknis yang dikeluarkan oleh pejabat yang berwenang menjadi rencana dan pengarahan yang tepat agar dapat terlaksana dengan baik, maka perlu untuk mengetahui siapa-siapa saja yang bertanggung jawab pada program tersebut, kemudian dalam pelaksanaannya apakah sudah sesuai. Dimana pemerintah harus dibekali dengan strategi-strategi agar setiap kebijakan yang disosialisasikan kepada masyarakat berjalan aktif. Dalam hal ini pemerintah mengadakan sosialisasi untuk mengatasi kendala dari masyarakat, namun dalam pelaksanaannya Dinas Sosial, LK3 dan pekerja sosial yang bertanggung jawab terhadap kelancaran program sosial LK3 dalam menangani kasus kekerasan dalam rumah tangga ini, pemerintah juga berkoordinasi dengan pekerja sosial di sekitar lingkungan yang ada tokoh masyarakat dan pihak-pihak terkait lainnya.

Hasil wawancara dan observasi berdasarkan yang peneliti lakukan kepada bidang pemberdayaan sosial dan penanganan fakir miskin dan ketua LK3 Padang Pariaman terlihat bahwa yang bertanggung jawab dalam program sosial LK3 dalam menangani kasus kekerasan dalam rumah tangga adalah Dinas Sosial, karena program ini menangani persoalan sosial yang ada di masyarakat. sedangkan yang turun langsung kelapangan dalam melaksanakan program sosial LK3 dalam menangani kasus kekerasan dalam rumah tangga ini yaitu pekerja sosial sendiri, sedangkan keterlibatan dari pihak-pihak lain hanya sekedar membantu dalam pelaksanaan program tersebut. dan peneliti melihat bahwa tidak hanya Dinas Sosial yang bertanggung jawab terhadap kelancaran program sosial LK3 dalam menangani kasus kekerasan dalam rumah 
Dila Antari, Karjuni Dt. Maani I Implementasi Kebijakan Program Sosial oleh Lembaga Konsultasi Kesejahteraan Keluarga(LK3) dalam Menangani Kasus Kekerasan dalam Rumah Tangga di Lubuk Alung Kabupaten Padang Pariaman

tangga ini. Karena bahwa dinas sosial bukan sebagai pelaksana teknis di lapangan tetapi pekerja sosial sendiri lah yang langsung turun kelapangan untuk menyelesaikan masalah KDRT di dalam keluarga masyarakat. pelaksanaan kebijakan program sosial LK3 dalam menangani kasus KDRT pemerintah sudah melaksanakan sesuai dengan peraturan menteri sosial republik indonesia Nomor 25 Tahun 2017, dan pelaksanaan yang dilakukan oleh pemerintah juga di lakukan dengan cara sosialisasi ke masyarakat dengan cara datang ke perkecamatan dan di ikuti oleh camat, wali nagari, kapolsek dan pekerja sosial LK3 Padang pariaman, dengan melibatkan beberapa masyarakat di kecamatan tersebut. memberikan informasi kepada masyarakat salah satu tujuan sosialisasi tentang program Sosial dari LK3 dalam menangani kasus kekerasan dalam rumah tangga. Tetapi kenyataannya pelaksanaan pemerintah melakukan sosialisasi kepada masyarakat masih kurang di kerena kan masih ada masyarakat yang belum mengetahui dengan ada nya program LK3 dalam menangani kasus KDRT di lubuk Alung Kabupaten Padang Pariaman.

\section{Pengorganisasian}

Dalam pelaksanaan program sosial LK3 dalam menangani kasus kekerasan dalam rumah tangga dimana didalamnya harus memiliki struktur pelaksanaan program demi kelancaran suatu program, agar dapat mempermudah pelaksanaanya. struktur organisasi pelaksanaan program sosial LK3 di Lubuk Alung yaitu ketua dari program LK3 ini adalah bapak Rahmat Tk Sulaiman, dan wakilnya sendiri yaitu bapak Ali Arifin, sekretaris nya yaitu bapak Ramadhanil, dan bapak Armayedi Tanjung, dan Bendahara nya yaitu ibu Mira, ibu Teta dan ibu Ponimin. dan tidak hanya itu, namun ada juga tokoh masyarakat yang lainnya ikut berpatisipasi juga dalam melaksanakan program sosial LK3 ini, dan yang bertanggung jawab penuh dalam pelaksanaan program sosial LK3 dalam menangani kasus KDRT ini yaitu pekerja sosial karena merupakan perpanjangan tangan dari Dinas Sosial sendiri.

\section{Penerapan}

Penerapan adalah berupa petunjuk pelaksana dan petunjuk teknis dari peraturan/kebijakan yang berjalan sesuai dengan ketentuan. perlu dilakukan untuk menentukan apa saja yang dilakukan serta lebih mudah untuk melaksanakan program tersebut agar dapat memudahkan apa saja untuk menentukan. dalam sosialisasi yang di adakan pemerintah selain membahas tentang prosedur, pemerintah juga mensosialisasikan kepada masyarakat tata cara pelaksanaan program ini yang merupakan syarat dari kegiatan program sosial LK3 dalam menangani kasus KDRT di Lubuk Alung. Selain itu prosedur peraturan tentang dan kebijakan yang ada kurangnya pengetahuan masyarakat merupakan salah satu penyebab terbanyaknya tindakan indisipliner dan pengaturan waktu yang kurang maksimal mengakibatkan program kerja yang ditetapkan tidak terlaksana sesuai waktu yang ditentukan sehingga koordinasikan yang dilaksanakan sangat minim. Dalam hal ini pemerintah melaksanakan kegiatan program terlebih dahulu melakukan dengan pendekatan kepada masyarakat tentang apa saja manfaat dari pelaksanaan program sosial LK3 dalam menangani kasus kekerasan dalam rumah tangga tersebut, kemudian mengikutsertakan masyarakat dalam setiap kegiatan, tujuannya supaya program ini efektif karena sesuai dengan kehendak dan kemampuan serta kebutuhan masyarakat.

Mengenai prosedur program sosial LK3 dalam menangani kasus kekerasan dalam rumah tangga yaitu dengan pertama klien datang ke LK3 untuk mengadukan atau berkonsultasi dalam masalah KDRT yang di alami oleh klien, lalu sekretaris menerima dan mencatat identitas serta permasalahan yang dihadapi klien, dan ketua LK3 menugaskan kepada tenaga 
Dila Antari, Karjuni Dt. Maani I Implementasi Kebijakan Program Sosial oleh Lembaga Konsultasi Kesejahteraan Keluarga(LK3) dalam Menangani Kasus Kekerasan dalam Rumah Tangga di Lubuk Alung Kabupaten Padang Pariaman

profesional untuk melakukan konsultasi kepada klien,dan apabila tenaga profesional tidak mampu menyelesaikan masalah klien dengan cara konsultasi maka pekerja profesional melaporkan kepada keteua LK3 untuk merujuk ke dinas terkait yaitu kedinas pengadilan agama atau ke ahli agama dan psikolog, dan lalu ketua LK3 menugaskan sekretaris untuk membuat surat rujukan ke dinas terkait untuk di proses lebih lanjut. Dan klien yang datang ke LK3 merupakan individu, kelompok, atau masyarakat yang mengalami masalah keluarga terutama KDRT. Bagi LK3 merekrut klien bukan hal yang dipentingkan, LK3 membantu siapapun dan dari latar belakang apapun klien yang datang adalah fokus utama yang dilakukan LK3. Dalam perekrutan klien yang dilakukan LK3 yaitu secara langsung dan sukarela mendatangi LK3 yang terdekat/tersedia di lokasi tempat tinggalnya, atau melakukan kontak awal dengan LK3 berdasrkan rujukan dari petugas sosial atau kader-kader di bidang pelayanan kesejahteraan sosial setempat, dan dalam hal ini LK3 tidak memungut biaya sepersen pun dari klien atau masyarakat, dan masyarakat bisa menghubungi LK3 melauii email, kontak telfon/ cell center yang tersedia dan juga dengan model jemput bola.

Dalam melihat apa saja faktor-faktor yang mempengaruhi Implementasi Kebijakan Program Sosial Lembaga Konsultasi Kesejahteraan Keluarga (LK3) dalam menangani kasus kekerasan dalam rumah tangga penulis melakukan penelitian khususnya di Lubuk Alung, maka dari itu penulis menggunakan indikator Penilaian yang merupakan faktor-faktor yang mempengaruhi Implementasi Kebijakan Program Sosial LK3 Dalam Menangani Kasus Kekerasan Dalam Rumah Tangga (KDRT) di Lubuk Alung Kabupaten Padang Pariaman yang di kemukakan oleh George Edward III yaitu Komunikasi, Sumber daya, Disposisi, Struktur Birokrasi.

\section{Komunikasi}

Dalam Implementasi Program Sosial Lembaga Konsultasi Kesejahteraan Keluarga (LK3) dalam menangani kasus KDRT ini, komunikasi yang dilakukan oleh pemerintah kepada masyarakat salah satunya dalam bentuk Sosialisasi yang dilakukan oleh Dinas terkait kepada masyarakat. sosialisasi merupakan salah satu bentuk komunikasi yang dilakukan oleh pemerintah kepada masyarakat agar tercapainya tujuan suatu kebijakan atau program yang dilakukan. Komunikasi ini diperlukan untuk menyampaikan informasi dari pembuat kebijakan kepada pelaksana kebijakan dan di efektifkan lagi dengan di sampaikan juga kepada kelompok sasaran kebijakan, adapun indikator dalam komunikasi ini yaitu Transmisi, Kejelasan, dan Konsisten. Dalam komunikasi Program Sosial Lembaga Konsultasi Kesejahteraan Keluarga (LK3) dalam menangani kasus KDRT ini kejelasan informasi yang dilakukan masih kurang, hal ini dapat dilihat dari sosialisasi yang tidak jelas dan tidak tahunya masyarakat mengenai Program Sosial Lembaga Konsultasi Kesejahteraan Keluarga (LK3) dalam menangani kasus KDRT tersebut. Masyarakat yang masih belum sepenuhnya nya paham mengenai program sosial LK3 dalam menangani kasus KDRT ini khusunya di lubuk alung.

\section{Sumber Daya}

Dalam pelaksanaan sebuah program harus di dukung dengan sumber daya yang memadai. Perintah-perintah implementasi mungkin diteruskan secara cermat, jelas dan konsisten, tetapi jika para pelaksana kekurangan sumber-sumber yang diperlukan untuk melaksanakan kebijakankebijakan implementasi kebijakan Sumber daya memiliki peranan penting. Edward III dalam Winarno (2012) mengemukakan bahwa sumber-sumber dapat merupakan faktor yang penting dalam melaksanakan kebijakan publik. maka Implementasi ini pun cenderung tidak efektif. Sumber daya 
tersebut berupa sumber daya manusia, anggaran dan fasilitas.

Sumber daya manusia merupakan salah satu aspek terpenting dalam pelaksanaan sebuah program. Dalam pelaksanaan program sosial LK3 dalam mengani kasus KDRT sangat bergantung pada sumber daya manusia yang dimiliki, hal tersebut dikarenakan sumber daya manusia sebagai penggerak dari program sosial LK3 dalam menangani kasus KDRT khusunya ialah pekerja sosial LK3 yang ada di kabupaten padang pariaman.

Dalam pelaksanaan program sosial LK3 dalam menangani kasus KDRT ini terkendala terhadap sumberdaya manusia yang dibutuhkan untuk menjalankan program ini. Sumber daya manusia yang dimaksud berupa jumlah tenaga sosial LK3 yang dapat diturunkan kelapangan dalam menyelesaikan kasus KDRT di masyarakat. jumlah tenaga sosial yang dimiliki saat ini dan luasnya wilayah yang dimiliki kabupaten padang pariaman tidak sebanding dengan jumlah petugas sosial yang ada dan jumlah titik LK3 yang ada. Dimana jumlah petugas yang ada di dinas sosial LK3 sebanyak 7 orang, sedangkan kader yang dimiliki untuk menjalan program tersebut sebanyak 27 orang yaitu 3 orang dalam satu desa yaitu wali korong, ninik mamak, dan kepala pemuda, sedangkan desa yang ada di wilayah lubuk alung berjumlah 9 desa. Namun walaupun demikian perangkat desa yang dijadikan sebagai kader dalam menjalankan program dari LK3 dalam menangani kasus KDRT tersebut, tidak kesemua kader mengetahui fungsi dari Program LK3 dalam menangani kasus KDRT, dikarenakan sosialisasi yang dilakukan LK3 saat mengadakan penyuluhan tidak semua perangkat dari 9 desa yang mendapat undangan. Sehingga masih ada desa-desa yang ada di wilayah lubuk alung tidak mengetahui fungsi dan tujuan dari Program Sosial LK3 dalam penanganan KDRT tersebut.

Selain sumber daya fasilitas, sumber daya manusia atau sarana dan prasarana yang dimiliki juga dapat mempengaruhi pelaksanaan program sosial LK3 dalam menangani kasus KDRT. Tersedianya sarana dan prasarana yang cukup akan mempermudah pencapaian tujuan sehingga dalam pelaksanaan kegiatan bisa berjalan dengan lancar. peralatan dan perlengkapan yang secara langsung dipergunakan untuk menunjang proses suatu kegiatan adalah Pada dasarnya sarana. Sedangkan fasilitas yang secara tidak langsung menunjang jalannya suatu proses kegiatan yang dimaksud adalah prasarana.

Dari hasil penelitian dapat dilihat bahwa sumber daya peralatan yang ada kurang memadai untuk menjalankan program sosial LK3 dalam menangani kasus KDRT ini. Karena berbagai macam peralatan yang digunakan oleh pekerja sosial merupakan milik pribadi dari pekerja sosial tersebut. yang jumlah dan perlengkapannya terbatas sehingga dapat menghambat jalannya pelaksanaan program sosial LK3.

Selain sumber daya manusia dan fasilitas, aspek lain yang dapat mempengaruhi implementasi sebuah program khususnya program sosial LK3 dalam menangani kasus KDRT ini adalah sumber dana dari APBD dan anggaran bupati dan sumber dana lainnya yang sah dan tidak mengikat.

\section{Disposisi}

Jika pandangan aparatur pelaksana berbeda dengan pembuat kebijakan maka proses implementasi akan mengalami banyak masalah dan tidak tercapainya program yang telah dibuat. Tetapi Jika aparatur setuju dengan bagian-bagian isi dari kebijakan yang akan dan harus dilaksanakan maka mereka akan melaksanakan dengan senang hati. Adalah Salah satu faktor yang menunjang keberhasilan implementasi kebijakan adalah sikap implementor atau sikap para pelaksana kebijakan.

Karakteristik pelaksanaan dalam menjalankan program sosial LK3 masih belum maksimal karena masih ada pekerja 
Dila Antari, Karjuni Dt. Maani I Implementasi Kebijakan Program Sosial oleh Lembaga Konsultasi Kesejahteraan Keluarga(LK3) dalam Menangani Kasus Kekerasan dalam Rumah Tangga di Lubuk Alung Kabupaten Padang Pariaman

sosial LK3 yang belum menyelesaikan permasalah yang diajukan masyarakat. dan ini terlihat masih belum tuntasnya pekerja sosial dalam menangani kasus KDRT yang di alami oleh masyarakat.

\section{Struktur Birokrasi}

Struktur birokrasi memiliki pengaruh yang signifikan terhadap Implementasi Kebijakan. Aspek struktur birokrasi ini melingkupi dua hal yaitu mekanisme dan truktur birokrasi itu sendiri. Dalam pelaksanaan Program Sosial LK3 dalam menangani kasus KDRT Lubuk Alung Kabupaten Padang Pariaman ini merupakan instruksi langsung dari Bupati yang di serahkan kepada Dinas Sosial Pemberdayaan Perempuan dan Perlindungan Anak. Maka Program ini merupakan dibawah naungan dari Dinas Sosial Pemberdayaan Perempuan dan Perlindungan Anak yang menjadi koordinator untuk kegiatan di lapangan. Dinas Sosial Pemberdayaan Perempuan dan Perlindungan Anak disini bertugas untuk melakukan pengawasan dan evaluasi terhadap kinerja dari Pekerja Sosial. Pekerja Sosial ini yang akan turun langsung untuk melaksanakan pelayanan sosial kerumah masyarakat untuk menyelesaikan Pemasalahan KDRT yang dialami oleh masyarakat, maka disini masyarakat menjadi sasaran dari program ini selain itu dalam pelaksanaannya program sosial LK3 kabupaten padang pariaman juga melibatkan sektor lainnya seperti ahli psikologi, ahli agama, ahli pendidikan, ahli hukum, ahli kesehatan LK3 padang pariaman untuk keluarga, milik kita bersama.

Dalam pelaksanaan program sosial LK3 dalam menangani kasus KDRT kabupaten padang pariaman ini sudah memilki standart operasional prosedur yang memadai, dimana sistem pelaksanaan, anggaran serta tanggung jawabnya sudah jelas di dalam SOP tersebut. dan selain itu semuanya sudah di atur.

\section{PENUTUP}

Hasil penelitian yang dilakukan penulis Berdasarkan mengenai Implementasi Kebijakan Program Sosial Oleh Lembaga Konsultasi Kesejahteraan Keluarga (LK3) Dalam Menangani Kasus Kekerasan Dalam Rumah Tangga di Lubuk Alung Kabupaten Padang Pariaman maka dapat disimpulkan bahwa:

1. Implementasi Kebijakan Program Sosial LK3 khususnya di Lubuk Alung belum bisa dikatakan terlaksana dengan baik, karena dapat dilihat dari teori Charles O. Jones dalam implementasi masih terdapat masalah dari beberapa indikator yaitu :

a) Interpretasi, dimana dapat diketahui bahwa, pelaksanaan dalam bentuk yang dilakukan pemerintah yaitu sosialisasi kepada masyarakat masih kurang di kerena kan masih ada masyarakat yang belum mengetahui dengan ada nya program LK3 dalam menangani kasus KDRT di lubuk Alung Kabupaten Padang Pariaman.

b) Pengorganisasian, dalam pengorganisasian sudah tersusun dengan baik dimana LK3 memiliki ketua, wakil ketua, sekretaris dan bendahara. Serta ada juga tokoh masyarakat yang lainnya ikut berpatisipasi juga dalam melaksanakan program sosial LK3 ini, dan yang bertanggung jawab penuh dalam pelaksanaan program sosial LK3 dalam menangani kasus KDRT ini yaitu pekerja sosial karena merupakan perpanjangan tangan dari Dinas Sosial sendiri.

c) Penerapan, sudah tersusun dengan baik, kegiatan program LK3 dalam menangani kasus KDRT untuk kegiatan pengaduan atau berkonsultasi pada hari seni dan kamis, dilaksanakan baik di kantor sekretariat maupun di luar kantor sekretariat, tetapi selain dengan hari yang telah di tetapkan pihak LK3 sendiri bisa melayani pengaduan 
Dila Antari, Karjuni Dt. Maani I Implementasi Kebijakan Program Sosial oleh Lembaga Konsultasi Kesejahteraan Keluarga(LK3) dalam Menangani Kasus Kekerasan dalam Rumah Tangga di Lubuk Alung Kabupaten Padang Pariaman

dan berkonsultasi ke LK3 dengan selain hari yang di tetapkan, dan LK3 bisa menerima pengaduanya lewat email atau langsung lewat telfon.

Faktor-Faktor Implementasi yang mempengaruhi Program Sosial Oleh LK3 dalam penanganan kasus Kekerasan Dalam Rumah Tangga KDRT.

1. Komunikasi

a) Transmisi yang dilakukan pemerintah sudah disosialisasikan dengan baik oleh pemerintah yaitu dikantor bupati padang pariaman, dimana dalam sosialisasinya sudah mengundang beberapa perwakilan dari masyarakat dan tenaga sosial lainnya, dan selajutnya sosialiasi diselenggarakan kembali oleh pihak LK3 dan dinas sosial.

b) Kejelasan, bahwa komunikasi yang dilakukan oleh pemerintah kabupaten padang pariaman khususnya Dinas Sosial Pemberdayaan Perempuan dan Perlindungan Anak LK3 dalam menangani kasus kekerasan dalam rumah tangga di Lubuk Alung Padang Pariaman belum dilakukan dengan jelas dan tidak menyeluruh, khususnya komunikasi yang dilakukan kepada masyarakat.

c) Bahwa sosialisasi yang dilakukan oleh dinas sosial dan Lembaga konsultasi kesejahteraan keluarga (LK3) dalam menangani kasus KDRT kepada masyarakat dalam memecahkan masalah didalam rumah tangga hingga tindak kekerasan yang ada didalam rumah tangga belum konsisten karena dilihat masih banyak masyarakat yang belum mengetahui akan Program Sosial dari LK3 ini dan sosialisasi yang dilakukan oleh pihak LK3 sendiri juga belum maksimal karena wali nagari setempat juga belum pernah menerima undangan dari pihak LK3 dalam keikutsertaan bersosialisasi sehingga wali nagari sendiri pun juga belum mengetahui tentang program sosial LK3 ini dapat memecahkan masalah didalam rumah tangga bahkan KDRT sekalipun.

\section{DAFTAR KEPUSTAKAAN}

Abu Ahmadi, Haji. 2009. Psikologi Sosial. Jakarta: Rineka Cipta.

Aneta, Asna. 2010. Implementasi Kebijakan Program Penanggulangan Kemiskinan Perkotaan (P2KP) di Kota Gorontalo. Jurnal Administrasi Publik, Vol 1 No 1, Halm. 55-56.

Anggara, Sahya. 2014. Kebijakan Publik. Bandung : CV Pustaka Setia.

Djamarah, Syaiful Bahri. 2014. Pola Asuh Orang Tua dan Komunikasi dalam Keluarga. Jakarta : Rineka Cipta.

Indiahono, Dwiyanto. 2009. Kebijakan Publik Bebasis Dynamic Policy Analysis. Yogyakarta: Grava Media.

Komisi Nasional Anti Kekerasan Terhadap Perempuan.

Www.komnasperempuan.go.id .

Moleong, Lexy J. 2013. Metode Penelitian Kualitatif. Bandung: PT Rosdakarya.

Nasserie Latifah, Pedoman Lembaga Konsultasi Kesejahteraan Keluarga, Dinas Kesejahteraan Sosial Bagian Proyek Pemberdayaan Peran Keluarga. Bengkulu.

Pasolong, Harbani. 2007. Teori Administrasi Publik. Bandung: Alfabeta.

Peraturan Menteri Sosial Republik Indonesia Nomor 25 Tahun 2017 Tentang Lembaga Konsultasi 
Dila Antari, Karjuni Dt. Maani I Implementasi Kebijakan Program Sosial oleh Lembaga Konsultasi Kesejahteraan Keluarga(LK3) dalam Menangani Kasus Kekerasan dalam Rumah Tangga di Lubuk Alung Kabupaten Padang Pariaman

Kesejahteraan Keluarga.

Peraturan Menteri Sosial Republik Indonesia No 84 Tahun 2010 Tentang Program Sosial Lembaga Konsultasi Kesejahteraan Keluarga.

Samsudin, Dede. 2019. Peran Lembaga Konsultasi Kesejahteraan Keluarga (LK3) Mitra Sejahtera Dalam Upaya Pencegahan Angka Perceraian di Kota
Manna. Qiyas, Vol 4 No 2.

Undang-Undang Hukum Pidana Pasal 1 Nomor 23 Tahun 2004 Tentang Penghapusan Kekerasan Dalam Rumah Tangga.

Winarno, Budi. 2012. Kebijakan Publik Teori, Proses, Dan Studi Kasus. Yogyakarta: Buku Seru. 